\title{
Response to Karen Bauer's Review of The Study Quran
}

\author{
Maria Dakake and Joseph E.B. Lumbard \\ General Editors, The Study Quran
}

In her review of The Study Quran in AJISS (34:4), Karen Bauer makes a number of broad claims about the authors' ideology and methodology, particularly in producing the commentary that accompanies the translation. Her claims regarding the commentary, however, seem to be based on a limited reading of the text, which has led her to make a number of otherwise inexplicable factual errors. For example, in assessing the SQ authors' selection, use, and representation of Islamic tafsir sources in the commentary, she overlooks the note in the front matter entitled, "Understanding the Citations in the Commentary" - which makes it clear that, in the interest of saving space, the citation of various commentaries as sources for the opinions mentioned in the Study Quran commentary is done through a system of abbreviations, for which a key is provided on pages lvii-lix.

This abbreviation system means that commentators are not usually cited by their full names in the text itself. Their names are occasionally cited in full, and then only in cases when an SQ author is citing an opinion expressed by that the commentator, rather than a view the commentator is merely reporting from other sources. Her misunderstanding of this citation method leads her to significantly miscount and underrepresent the SQ authors' use of certain tafsir sources. Bauer is particularly critical of the SQ's heavy use of "medieval" sources and its purported neglect of post-medieval and modern tafāsìr. She writes:

In sum: Authors who died during the twentieth century or after are completely omitted from the commentaries; authors from the fifteenth to the 
nineteenth centuries are very rarely referenced, except for Ibn 'Ajỉbah, and authors of the fourteenth century and before have the most citations. (p. 71)

It is true that authors from the fourteenth century and earlier receive the most citations, al-Tabari (d. 310/923), al-Razi (d. 606/1210), al-Qurtubi (d. 671/1272), and Ibn Kathir (d. 774/1373) in particular. But Bauer makes no argument as to why this is problematic, and demonstrates no awareness of the differentiation between citations by full name and citations by abbreviated letter. Nor does she state which modern commentaries she would like to have seen cited and the advantages that would have been obtained by doing so.

It is clearly stated in both the introduction and the section on "Understanding the Citations in the Commentary" (lii-lv) that an effort has been made to cite commentaries that have had broad influence over time and are widely available. Later commentaries, especially those of the twentieth century, would thus logically be cited less often, because they have had less time to establish their influence. Many later commentaries also offer large swathes of material that duplicate material in earlier commentaries.

More importantly, Bauer's contention that later authors are rarely cited is factually incorrect, and rather dramatically so. For example, Bauer claims that Tabataba'i (d. 1981) is "only represented in the introduction and two of the essays" (p. 71). Yet Tabataba'i (abbreviated as Tb) is cited 67 times in the commentary. She claims that Biqāi i is not cited in the commentary at all, but only in the introduction and one of the essays. In fact, Biqa $i$ (abbreviated $\mathrm{Bq}$ ) is cited over 30 times in the commentary. This is but the tip of the iceberg. Bauer also states,

The early modern author Shihab al-Din al-Alusi (d. 1854) is referenced in the commentary on four verses (Q. 24:31, 33:56, 51:56, 58:22), alShawkani (d. 1839) is referenced in the commentary on two verses (Q. 93:1-2), while the Shadhili Sufi Ibn 'Ajibah Ahmad (sic) (d. 1809), is referenced in some forty-six passages, some of them including several verses. (p. 71)

The statement above discounts more than 900 citations. Alusi (abbreviated $\overline{\mathrm{A}}$ ) is cited 176 times; Shawkani (Sh) is cited more than 160 times; and Ahmad Ibn 'Ajiba (Aj) is cited 568 times. Bauer also writes, "Al-Suyuti (d. 1505) is referred to in the commentary on two verses" (p. 71). While al-Suyuti's 
major commentary al-Durr al-manthür (abbreviated as Sy) is only cited thirty-seven times, the commentary known as al-Jalälayn (JJ), which was begun by al-Suyuti's teacher, Jalal al-Din al-Mahalli (d. 1459), and completed by Suyuti himself (and for which he is thus considered a co-author), is cited more than 600 times. A table illustrating the difference between Bauer's assertions regarding the SQ's use of particular commentators and their actual usage in the SQ commentary shows that she has missed well over a thousand citations, just in the claims she makes about a relative handful of commentators cited in the SQ:

\begin{tabular}{lcc} 
Author & Bauer's count & Actual count \\
\hline Tabataba'i & 0 & 67 \\
Burusawi & 1 & 14 \\
Muhsin Fayd Kashani & 0 & 15 \\
Alusi & 4 & 176 \\
Shawkani & 2 & 160 \\
Ibn 'Ajiba & 46 & 568 \\
Suyuti (Sy and JJ) & 2 & $600+$
\end{tabular}

These oversights amount to a complete misrepresentation of the scope, breadth, and methodology of The Study Quran commentary, and can only be explained by the fact that her statistical analysis relied exclusively on the method of looking up these few names in the index (which would only note the pages on which the names appeared in full, not in abbreviated form in which they are usually found). Bauer seems to understand how the citation methodology works when she states that the commentary on 4:34 "relies mostly on al-Tabari and al-Qurtubi, but also mentions Ibn Kathir, al-Tabrisi, al-Zamakhshari, and others" (p. 73), yet still misrepresents the way the SQ cites and uses sources in her analysis of the SQ's use of later tafasir.

The review makes several other misrepresentations, as when the translation of ittaqu in 4:1 as "reverence" is presented as an effort to render the word in a "modern context" that is indicative of the "modern conservative approach." (p. 72) Bauer has not done the basic work of cross-referencing other translations of the same term in the SQ, nor has she examined the authors' translation of other words such as khashiya and khawf for which "fear" is used in the translation, as in 2:74, "among them are those that crash down for the fear of God (khashyati-lläh)," or 21:49, 35:18, 39:23, and 67:12, which speak of "those who fear their Lord." Ittaqu and ittaqi are consistently rendered as "reverence" throughout, and al-mutaqqūn/in is rendered 
"the reverent." This differentiates the translation of ittaqu $\bar{u}$ and related terms from other terms rendered as "fear" (which occurs over 170 times in the translation) and captures a broader range of the meaning of taqwā. In the commentary on the first instance of a word deriving from this root ( $\mathrm{Q} 2: 2)$, Caner Dagli explains,

Reverent translates muttaqin, which comes from the central Quranic concept of taqwā, rendered in this translation as "reverence." Taqwa comes from the root $w-q-y$, which evokes the sense of wariness, care, and protection. As it concerns the attitude of human beings toward God, taqwa conveys the sense of fear, mindfulness, and a constant awareness of God's Presence and Power. (SQ, 14-15)

Despite a very clear explanation of this translation choice, and extensive discussions of taqwā in the commentaries on eleven other verses, as indicated in the index, the translation is dismissed without any effort to research the manner in which the term is rendered and discussed throughout the book under review.

In reviewing the content, Bauer fails to observe the need for concision in order to produce a single volume study text. She ironically singles out 4:1 and 4:34, two of the verses with the most extensive commentaries in the volume, for what she asserts is not included. For example, she claims that Maria Dakake (the author of the commentary on 4:34) does not include "the reasons given by the medieval commentators to justify the husbands superior position in the marital relationship," and further writes, "she never alludes to male authority" (p. 73). Yet far from merely "alluding" to male authority, Dakake addresses the issue directly in her commentary, writing with regard to the authority of husbands, as seen by medieval commentators:

For Ibn 'Ajïbah, this is "acquired" authority, since men's more authoritative position in the marital relationship is "acquired," at least in part, by their fulfillment of the duty to support the women of their family including, but not limited to, their wives. Many commentators and the Mālikī and Shāfíi legal schools considered men's authority and financial responsibility in marriage to be directly linked (Țs), so that a man who did not support his wife could no longer claim authority over her $(\mathrm{Q})$, although for al-Qurtubī, such a situation constituted a nullification of the marriage contract. Many commentators also claimed, however, that the "favor" that God has shown to men also includes spiritual and worldly distinc- 
tions not necessarily related to financial matters. Among the distinctions they considered to have been given exclusively or in greater measure to men were intelligence, authority, strength, and the responsibility for $j i-$ $h \bar{a} d$, some also assert that all prophets and most scholars and authorities were men (Aj, IK, Q, Ț, Ṭ, Z). (SQ, 206-207)

Although 4:34 is one of less than a handful of verses whose commentary she claims to have examined closely, she has clearly not read the text very closely at all, for one can also see in the latter part of the quote cited above, Dakake does in fact address and summarize the "reasons" medieval commentators gave to justify male authority. Dakake goes on to critically suggest that the interpretation of male authority on the part of medieval commentators seems too expansive to be justified by narrow focus of the surrounding passage, which is focused on issues of financial support in the family. Nonetheless, Bauer dismisses this and Dakake's other critiques of the positions of medieval commentators as an example of a "modern conservative" approach to the text, which is never defined.

Having (apparently) reviewed the commentary on only four verses that pertain narrowly to her own research and having said nothing about the extensive companion essays, Bauer has failed to address how the SQ deals with a range of verses and issues. To render judgment on a 2000-page work that took a decade to produce, carelessly slap an undefined ideological label on its established editors and authors, and make sweeping and inaccurate assertions about its research methodology, all on the apparent basis of scanning the table of contents, examining the commentary on four verses (which takes up only 5 pages of the commentary), and checking 8 names in the index is unacceptable by any scholarly standard.

Maria Dakake Associate Professor of Religious Studies George Mason University

Joseph E.B. Lumbard Associate Professor of Arabic and Translation Studies American University of Sharjah 